\title{
Procedures and Practice Before the California State Water Rights Board
}

\author{
Henry Holsinger';
}

A reorganization of the powers, duties, and responsibilities of various governmental agencies of the state having functions relating to water was accomplished at a special meeting of the California legislature which convened concurrently with the 1956 budget session. By chapter 52 of that special session the offices of the then Division of Water Resources, of the Department of Public Works, and its chief, the State Engineer, were abolished, but their functions were preserved and divided between a newlycreated Department of Water Resources ${ }^{1}$ and an independent three-member board, denominated the State Water Rights Board. ${ }^{2}$ One of these members is required to be an attorney and another an engineer. ${ }^{3}$ All are appointed at large by the Governor, ${ }^{4}$ but are removable only for cause by a majority of the menibers elected to each house of the legislature. ${ }^{5}$ The Governor also designates a member to serve at his pleasure as Chairman. ${ }^{\circ}$ All hearings and meetings of the Board are required to be open to the public. ${ }^{7}$

A major function of the Board is the administration of the statutory law relating to the appropriation of the unappropriated, or unused, water of the state. The practice and procedure of the Board in the administration of these statutes is the subject of the discussion which follows. This function has an extensive legislative history, beginning December $19,1914 .^{\circ}$ The present statutes concerning it are found in Division 2, Part 2, of the Water Code. These are extensive, comprising 158 sections, ${ }^{9}$ and are supplemented by a 34-page printed pamphlet ${ }^{10}$ containing detailed rules and regulations formulated over the 43-year period since the function was first authorized by the legislature. This pamphlet also contains eight pages of general information concerming water rights. This informative publication is freely available to all. To secure a copy one need ouly write the Board at its Sacramento office, requesting a copy of its current rules and regula-

* Member, Sacramento Bar; Chairman, State Water Rights Board.

1 CAL. Water CODE $\$ \S 120-63$.

2 Id. $\$ \S 175-88$.

3 Id. $\$ 175$.

4 Ibid.

5 Id. $\$ 178$.

B Id. \&182.

TId. $\$ \S 181,183$.

8 Effective date of Water Commission Act, Cal. Stat. 1913, c. 586.

${ }^{\circ}$ CaL. Water CODE $\$ \S 1200-1801$.

10 Cat. State Water Rights Board, Rutes, Regulations and Information Pertaining to Appropration of Water IN CALIFORNIA (1957). 
tions relating to the appropriation of water; a copy will be mailed free of charge. Also, an article by Hugh W. Ferrier, which appeared in the December 1956 issue of the California Law Review, ${ }^{11}$ includes an excellent review of the subject here under discussion. Due to the availability of this material it is unnecessary to attempt a comprehensive coverage of the subject but rather a broad picture of the practice and procedure of the Board in carrying out this very important function will be painted.

Administration of the water appropriation statutes is not the sole activity which has been delegated to the Board by the legislature. ${ }^{12}$ There are two others: assistance to the courts and parties in adjudication of water rights, ${ }^{13}$ and administration of Part 5 of Division 2 of the California Water Code, ${ }^{14}$ enacted by the 1955 session of the legislature, ${ }^{15}$ providing for recordation of extraction of ground water and diversion of surface water. The latter is restricted in operation to five southern California counties. ${ }^{16}$ The Board's functions under it are of a ministerial character. The former function, relating to adjudication of water rights, is to a limited extent quasijudicial and the required practice and procedure would doubtless be of interest. Adequate coverage of that subject is, however, beyond the scope of this paper which will be limited to the administration of the appropriation of water.

Because the present audience is particularly interested in quasi-judicial functions relating to water, there is added reason for restricting the scope of this paper. Administration of the law of appropriation of water is far more quasi-judicial in nature than other Board functions. This is so because the practice and procedure required of the Board by statute and by the applicable rules and regulations in carrying out this function is closely akin to that followed in trial courts. There is, however, a sharp distinction between the function of the Board, for example, in hearing and deciding contested apphications to appropriate water, and that of a court in exercising similar functions. In such case the court would be passing on past and present facts in order to determine and to declare present rights and obligations; the Board, in contrast, directs its viewpoint to the future and only considers past and present facts to guide it. For example, in making reasonable estimates of future flow conditions in the particular source involved,

11 Ferrier, Administration of Water Rights in California, 44 CAITF. L. REv. 833 (1956).

12 By Cax. Water Code $\S 179$, formerly id. § 189, added by Cax. Stat. 1956, c. 52, § 7, the State Water Rights Board succeeded to "all of the powers, duties, purposes, responsibilities, and jurisdiction" theretofore vested in the Division of Water Resources of the Department of Public Works under Parts 1, 2, 3, and 5 of Division 2 of the Water Code.

13 CaL. Water Code $\$ \S 2000-900$.

14 Id. \$\$ 4999-5008.

15 Cal. Stat. 1955, c. 1869.

10 Riverside, San Bernardino, Los Angeles, Ventura, and Santa Barbara. 
having due regard to the requirements of the public interest, the Board prescribes rules for the future. ${ }^{17}$ Its function therefore in fact partakes more of a legislative nature than it does of a judicial character. ${ }^{18}$

\section{ADMTNISTRATION OF THE APPROPRIATION OF WATER}

In an approach to the subject of practice and procedure of the Board, it is necessary to recognize that the subject has an extensive background, not only of statutes, but also of constitutional provisions and case law, which must be duly observed by the Board and the parties appearing before it. Of the numerous background Code sections one stands out as highly significant: ${ }^{19}$

All water within the State is the property of the people of the State, but the right to the use of water may be acquired by appropriation in the manner provided by law.

Here it is necessary to discriminate between the ownership of the natural resource and the ownership of rights to its use. The latter is entirely compatible with the former. It therefore follows that the Board, in granting or denying permits and licenses as guided and controlled by the public interest, is not dispensing a public gratuity but is carrying out strictly a governmental function. It is in fact carrying out a public policy delegated to it by the people through the legislature.

The "manner provided by law" respecting this function, as provided in section 102 of the Water Code, is in a very real sense the subject of the present discussion. Vested rights are unaffected by lawful acts of the Board. Conformably thereto, all permits and licenses issued by the Board are therein declared to be "subject to vested rights."20 It has indeed been expressly stated by the California Supreme Court that in carrying out this function it is the first duty of the Board to protect existing rights. ${ }^{21}$ While much might be said respecting relevant constitutional provisions in this context, comment thereon will be limited to distilling therefrom that riparian rights are recognized in the California Constitution but limited to the now universally-apphicable rule of reasonable use under reasonable methods of diversion and use. ${ }^{22}$ This requires discarding a number of time-honored precedents. Many others, however, are still available for guidance of the

17 Cf. Temescal Water Co. v. Department of Public Works, 44 Cal. 2d 90, 280 P.2d 1 (1955).

18 East Bay Municipal Util. Dist. v. Department of Public Works, 1 Cal. 2d 476, 35 R.2d 1027 (1934).

19 CAL. WATER CODE $\$ 102$.

20. Cat. State Water Rigets Board, Rules, Regulations and Inforaration Pertatnino to Appropriation of Water iN CaLIFORNIA 33 (1956).

21 Meridian, Ltd. v. San Francisco, 13 Cal.2d 424, 450, 90 P.2d 537, 550, 91 P.2d 105 (1939).

22 Car. Const. art. 14, § 3 (1928). 
Board in carrying out this function. No more will be said at this point respecting case law as precedent than to refer the reader to the exhaustive volume by Wells A. Hutchins, recently published by the California State Printer. ${ }^{23}$

Turning to the process of appropriation, water subject thereto comprises sources which are replenished by natural processes, including water that may have been previously used but which has been allowed to escape from control and to commingle with a natural source of supply without overt intent to recapture. Subjects in the law of waters in California where generalities are at all safe are few indeed, and over-simplifications are common defects of statement; the definition above might easily be expanded but we are looking for the trees rather than the brush.

One important source of water supply subject to appropriation, underground percolating water, is not subjected to the jurisdiction of the Board. While this is well settled, both by case law and by statute, ${ }^{24}$ an apparent exception exists; an appropriation of a surface source may be made for storage underground, provided the water is later extracted and apphed to beneficial use. ${ }^{25}$ An insufficient nunber of such appropriations have as yet been fully processed to enable demonstration of whether this is entirely practical.

\section{A. Procedure for Appropriation}

The process of appropriation is intiated by filing with the Board an application on a provided form..$^{26}$ By this first step a right of procedural priority as against other subsequent conflicting applications is acquired. ${ }^{27}$ Assuming the application to have met the minimum requirements to establish a priority, it fixes the priority date to which a right to use the water, when acquired in the future, will "relate back." ${ }^{28}$ Meanwhile, the application consists of a conditional right of priority to the future use of water, which may be defeated by a number of future events. It is nevertheless a valuable property right so long as maintained according to legal requirements. Note will be taken that such right is brought into being by a publicly announced intent. This was said by the court of the posting and recording of a notice of appropriation of water in effect long prior to the present system of state supervision, ${ }^{29}$ but is equally true of the application to appropriate water under existing law.

The second essential step in the process is issuance by the Board of a

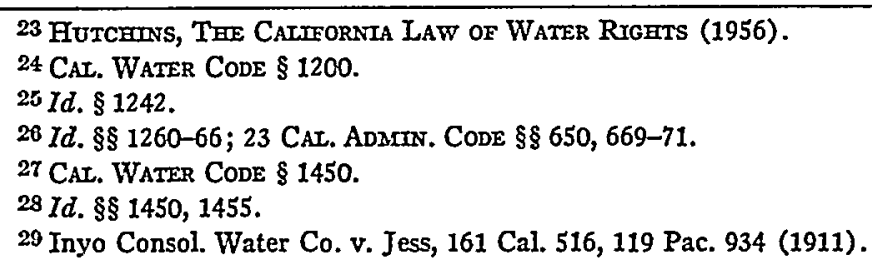


permit. The legal effect of the permit is two-fold: (1) It expresses the consent of the state to the future acquisition of a right by appropriation, limited by the terms of the permits. ${ }^{30}$ (2) It sets forth the prescribed criteria pursuant to which the future use is required to conform. ${ }^{31}$ Progress in construction and application of water to beneficial use is required to be reported annually. ${ }^{32}$ To the extent that use is made in accordance with the permit a right to continue the use is acquired. ${ }^{33}$ During the application stage due diligence must be exercised in completing the application. ${ }^{34}$ The penalty for failure is cancellation of the application..$^{35}$ During the permit stage diligence must be exercised in completion of the diversion and the storage works if any, and also in applying the water to beneficial use. ${ }^{36}$ The penalty for failure to comply is revocation of the permit in whole or in part. ${ }^{37}$

The third essential step is the issuance of a license. When the intended use under the permit is completed to the full extent contemplated, such completion is reported to the Board.$^{38} \mathrm{~A}$ representative of the Board makes a field inspection and reports in writing to the Board as to the extent water has been continuously used and other conditions fulfilled as prescribed in the permit, ${ }^{39}$ and a license is issued or denied accordingly.$^{40}$ No hearing is required for issuance but a hearing must be held to revoke or to deny issuance of a license. ${ }^{41}$ From the filing of the application through the issuance of a license, due diligence is required. ${ }^{{ }^{2}}$ After a permit is issued and water is used in conformance with the permit, a right to the use of water vests to the extent of such use, ${ }^{43}$ but at all times, even after a license is issued, the acquired right is subject to loss by forfeiture for failure to use the water, when available, for a period of three successive years. ${ }^{44}$

\section{B. Incomplete Applications, Notice, Protest, and Hearings}

A brief portrayal will now be given of the processing by the staff of incomplete applications, issuance of notice of filing application, publication

30 Cal. Water Code $\$ 1381$; Cal. State Water Rights Board, Rules, Regulations and Ifforacation Pertaining to Aprropriation of Water in Catifornia 4 (1957).

31 CaL. Water CODE $\$ \S 1391-92$.

3223 CaL. ADMañ. Code $\$ 779$.

33 CaL. Water Code $\$ \S 1390,1455$.

34 Id. $\$ \$ 1270-71 ; 23$ CAL. ADMTN. CODE $\$ 776$.

35 Cal. Water Code $\$ 1271$; 23 CaL. Adams. Code $\$ 695$.

36 CaL. Water Code $\S 1396 ; 23$ CaL. Admin. Code $\$ 776$.

37 Cal. Water Code $\$ 1410$.

38 Id. $\$ 1600$.

39 Id. \$ 1605 .

40 Id. $\$ \S 1610-11$.

41 Id. $\$ 1611$.

42 Notes 34-37 sucpra.

13 CaL. Water Code $\$ \S 1390,1455$.

14 Id. $\$ 1241$. 
of notice, receipt of protests and answers thereto, and other matters prior to hearing. An application is accepted for filing even though it does not contain all the required information, provided that it contains the minimum information requisite to establish a priority - a major objective of the application. ${ }^{45}$ In general, if the application is accepted for filing, it is reviewed by the engineering and legal staffs of the Board and, if found to be incomplete, the applicant is notified of the further information required, which must be supphed within sixty days, or within such further period which for good cause may be allowed for the purpose. ${ }^{46}$

When complete, the next step is the issuance and publication of notice of the filing of the application. In cases where small quantities of water are applied for, posting is sufficient; ${ }^{47}$ other cases require publication. ${ }^{48}$ This notice invites protests by parties who believe that they would be adversely affected by the proposed appropriation. The applicant is required to answer each protest which the Board determines to be valid. ${ }^{49}$ Clear and concise language is all that is required of protests and answers thereto. ${ }^{50}$ The application is then ready for hearing. If no protest is filed no hearing is necessary but the Board may nevertheless hold one. ${ }^{51}$ The reason for this election at the discretion of the Board lies in its authority to determine the public interest. Manifestly, there might be a case wherein a protest were to be offered too late to be entertained by the Board, yet the protestant might be an applicant under a later application whose project might have stronger elements of public interest in its support. In such a case, even though no protest were on file, the Board would clearly be justified in electing to hold a hearing, the primary purpose of which would be to ascertain what the public interest might require. Not less than twenty days notice of a hearing to interested parties is required. ${ }^{52}$ Also, not less than five days notice to the Board of intention to attend the hearing is required of applicants and protestants. ${ }^{53}$

On occasion, the Board may delegate to one or two members authority to hold hearings on its behalf, but in such cases the full Board considers the transcript and acts thereon. ${ }^{54}$ In the more important cases all three members sit en banc, with the Chairman acting as the presiding officer, who makes all rulings on admissibility of evidence and issues other orders as

45 Id. \$ 1270; 23 CAC. ADMIIN. Code \$\$ 692-94.

46 CaL. Water Code $\$ \$ 1270-71 ; 23$ CaL. AdMnn. Code $\$ 695$.

47 Cax. Water Code $\$$ 1320-23; see 23 CaL. Admin. Code $\$ 712$.

48 CaL. Water Code $\$ \$ 1310-16$; see 23 Cax. AdMmin. Code $\$ 712$.

4923 CAL. AdMIN. CODE $\$ 723$.

so See $i d . \$ \$ 719,724$.

51 Cal. Water Code $\$ 1351$.

52 Id. $\$ 1340$.

6323 Cal. Admin. Code $\$ 730$.

54 CaL. Water Code $\$ 183$. 
required. The Board, by statute, ${ }^{55}$ is not bound by "technical rules of evidence," as applied by the courts, the objective being to secure for the record the essential facts by the most direct possible means. The Board interprets the applicable requirement to be that it must afford the parties before it a full and fair hearing, according the parties due process of law, and observing "fair play" in accordance with the American tradition as declared by the United States Supreme Court in Morgan v. United States. ${ }^{6 B}$

A qualified court reporter is in attendance at all formal hearings and keeps a verbatim record of the proceedings, witnesses are sworn and examined, first on direct by the applicant, then on cross by protestants, lastly by Board members if they desire, and by the staff on request to and approval by the Clairman. There is no expense of these hearings to the parties other than their required share of the expense of preparation of the reporter's transcript. These costs are apportioned as prescribed by the rules. Each party participating pays for the space in the record occupied by his direct testimony and by his cross-examination of adverse witnesses, plus an equal share of the portion of the record occupied by the Board members and the staff. ${ }^{57}$ Oral argument is allowed on request and briefs may be ordered filed. ${ }^{58}$ The parties may be represented by attorneys or agents, and when an appearance is entered by an agent or attorney he is recognized by the Board as fully controlling the case on behalf of his principal. ${ }^{50}$

Frequently in the case of applications for small quantities of water, the interested parties, with approval of the Board, resort to "proceedings in lieu of hearing." ${ }^{100}$ To invoke this procedure the parties enter into a written stipulation that any petition, application, or protest shall be submitted upon (1) the official records of the Board, including reports of field investigations, if any, (2) research and studies made by or on behalf of the Board relating to the issues involved, and (3) such relevant representations, records, and documents as the parties to the stipulation may submit. Under this procedure, in the event the Board make a field investigation, notice of the time and place of assembly is given to the parties to the stipulation and to other interested persons who may attend and offer information relevant to the issues. In its decision the Board is required to indicate the records, documents, and other data relied upon in determining the matter, and copies thereof constitute the transcript of evidence for the purposes of the proceeding. A report is rendered by the officer conducting the proceeding, to the Board, and action disposing of the issues is taken directly by the Board, or by a member of the staff authorized by it.

\footnotetext{
55 Id. § 1353; 23 Cax. Admin. Code $\$ 733$.

56298 U.S. 468 (1936).

6723 CAI. AdMTN, CODE $\& 734$.

58 Id. § 735.

${ }^{50} \mathrm{Id} . \$ 736$.

60 Id. \& 737 .
} 


\section{Court Review}

The Water Code provides for review of the ruling, order, decision, or other official act of the Board by the superior court of the county in which the apphicant seeks to divert water under the application involved, within thirty days after final action by the Board on the application. ${ }^{61}$ It is provided, in effect, that the court, on hearing the matter, shall grant a trial de novo, ${ }^{\infty}$ and is not bound by the record made before the Board, but the Supreme Court of California held in Temescal Water Co. v. Department of Public Works $s^{03}$ that the remedy for such review is a mandamus proceeding, pursuant to the Code of Civil Procedure ${ }^{64}$ and not the procedure set forth in the Water Code. By court review, presumably pursuant to similar mandamus proceedings, the validity of any orders and rulings of the Board directly affecting rights of interested parties may be tested.

A very substantial portion of the time of the Board is occupied in passing on requests for extensions of time for various purposes; prior to issuance of permit, to extend the time fixed for conpletion of applications; ${ }^{\text {es }}$ after issuance of permit, to extend the time fixed for beginning construction, for completion of construction, for commencenent, and for completion of application of the water to beneficial use.$^{66}$ Action on these extensions are all broadly discretionary, it being required that the requests be supported by showing of "good cause" therefor ${ }^{6 \tau}$ No such ruling has been attacked in court, but can be at any time an interested party considers that he is adversely affected thereby.

\section{Revocation}

Mention has heretofore been made that a failure to comply with provisions of a permit or license may result in its revocation. ${ }^{68}$ Frequently the Board has occasion to pass upon whether a permit or license should be revoked. Usually such matters are brought to the attention of the Board by its staff, following inspections. Quite commonly, such failures are brought before the Board for action following requests for extension of time to

${ }^{61}$ CAL. WATER CODE $\$ \S 1360-62$. In 1957 the legislature amended $\$ 1360$ and repealed $\$ \S 1361-63$ in conformity with the Temescal decision, note 17 supra. Cal. Stat. 1957, c. 947.

62 CAL. WATER CODE $\$ 1363$, repealed in 1957, note 61 sutpra. This section provided: "The court shall take such additional relevant and competent evidence as it may require or as may be submitted by the department or the party filing the petition for review. The court shall then render judgment, according to the weight of evidence adduced before it, affirming, reversing, or modifying the action of the department."

6344 Cal. 2d 90, 280 P.2d 1 (1955).

g CAL. Code CIV. Proc. $\$ 1094.5$.

60 Cas. Water Code $\$ 1271 ; 23$ Cat. Admen. Code $\S 694$.

o6 CAL. Water Code $\$ 1398 ; 23$ CaL. Adustr. Code $\$$ 776.5-77.

67 See, e.g., Car. Water Code $\$ 1398 ; 23$ Car. Admin. Code $\$ 777$.

68 See text at notes 37, 44 supra. 
complete application of the water under permit to beneficial use. At times non-compliance is reported by other interested parties and in response an inspection may be ordered. At other times "progress reports," which are required of permittees annually, ${ }^{69}$ may arouse suspicion justifying such inspection.

In any of these situations, a staff report, supported by an inspection report, is made to the Board indicating probable ground for revocation, particularly for failure for three consecutive years or more to apply the water to beneficial use under either permit or license. If the Board considers such action justified, it directs that an order issue to the permittee or licensee reciting the evidence as reported to the Board and directing the permittee or licensee to appear before the Board at a designated time and place, to show cause, if any he has, why the permit or license should not be revoked.

When the matter of the order is called for hearing, a reporter is in attendance and a transcript of the proceeding is kept with the same degree of formality as in case of a hearing on an application to appropriate water. Presentation is first made by the staff, usually by the Principal Attorney for the Board, who calls as witnesses such staff members as have made inspections. These are sworn and give their testimony under oath and are then subject to cross-examination. Then follows the respondent with his showing in response to the order to show cause.

If there is no response on behalf of the permittee or licensee, the matter is decided on the basis of the presentation made by the staff. In these matters, where such an order is issued to a permittee or licensee, it is usually the case that the permittee may have made use of a part of the water allowed in the permit, or that, of the water actually used, a part thereof has not been used for three years or more. In such cases, depending on the record facts, the Board frequently will direct that a license be issued for such amount of water as has been applied to beneficial use with the continuity required by law. The effect of such an order would of course amount to revocation of a portion of the water authorized to be diverted and used by the permit.

\section{E. Modification of Application, License or Permit}

The Water Code provides that the point of diversion, purpose, and place of use under an application, permit, or license may be changed, provided a showing is made that no other "legal user" will be injured by the change.70 "Legal user" is interpreted to mean lawful user and to include either a prior or later appropriator, a riparian owner, or owner of other basis of right. If necessary to adequately develop the facts a hearing is held for that purpose.

6923 CAT. ADNOTN. CODE $\$ 779$.

70 Cat. WaTer Code $\$ \S 1700-06$. 


\section{F. Additional Reforms of Practice and Procedure}

In the Temescal case ${ }^{71}$ the court noted that the exercise of this function of administration of statutes concerning appropriation of water is exempt from the Administrative Procedure Act. ${ }^{72}$ However, although aware of this exemption, the predecessor in authority of the Board ${ }^{73}$ was also cognizant that many of the procedures provided by that act had been carefully formulated for the purpose of assuring parties appearing before the administrative boards subject to the act that such boards would accord them the requirements of due process. The Board also fully appreciates that such is the case and therefore has adopted certain reforms, and improved others previously initiated, in order to conform as closely as feasible to those procedures, even though not expressly obligated to do so. A number of other reforms in practice or procedure have been adopted with other objectives in view. This paper will briefly set forth some aspects of a selected few of these.

The Board has by resolution provided that numerous extensions of time may be made by the staff of the Board without hearing, but when an extention is requested concerning a comparatively extensive development or otherwise important project, the required showing of good cause therefor shall be made by the party requesting the extension by a personal appearance before the Board. This showing must be made under oath. ${ }^{74}$

Also, the Board from the beginning of its operations has adopted the policy of a progressive tightening of the requirements of law respecting diligence. It is considered to be contrary to sound public pohicy not to hold applicants, permittees, and licensees strictly to account for any failure in required diligence when, due to the rapidly-expanding population of our state, others without doubt are or will soon be eager to appropriate the same water and to exercise due dliugence in applying it to beneficial use in conformity to legal requirements.

When a nunber of applications are pending on a stream system having a common factual background, the Board has followed the practice of consolidating all such applications for hearing and reporting the consolidated hearing by a common transcript in much the same manner as the courts long have done under closely analogous circumstances. The Board has deinonstrated by experience that this feature has served to materially shorten the record transcript, resulting in a substantial saving of time occupied in the hearing and a substantial saving in attendant expense.

Another practice followed by the Board has had a similar effect. When

71 Temescal Water Co. v. Department of Public Works, 44 Cal. 2d 90, 280 P.2d I (1955).

72 CAT. Govr. Code $\$ \S 11370-528$.

73 See note 12 supra.

74 Requests for extension of time are also discussed in text at notes 65-67 supra. 
a series of applications are considered proper for consolidation for purposes of hearing, as heretofore explained, or when the issues involved are otherwise complex or involved, prior to fixing a date for commencing the hearing the Board has adopted the practice of calling the parties into an informal conference somewliat analogous to the practice of federal and state trial courts in holding pre-trial conferences. The major objectives are to arrange for consolidating the applications for hearing, to select dates for hearing satisfactory to all concerned, to explore all feasible recourse to eliminate surprise and delay and to shorten the hearing, including arrangements for the parties in advance of hearing to exchange written qualifications of professional expert witnesses, and maps, charts, engineering analyses, and other items contemplated for introduction as evidence at the hearing, and to encourage stipulations among the parties directed to the same or other salutary ends. Also, when it appears that desirable objectives, including saving in time and expense, may thereby be secured, an office report is prepared, including, on occasion, a field inspection and a report thereon. This office report lists all evidence available to the Board which appears material to the issues to be heard, including relevant files of the Board, and states that there will be offered as exhibits at the hearing by the Board's staff such items as are entitled to official notice; the latter are listed by reference to titles only. Copies of this office report are mailed to the parties well in advance of the liearing and where a pre-hearing conference is called, also well in advance thereof, whenever practicable.

\section{CURRENT PROBLEMS}

The Board has a number of problems requiring solution. Prominent among these is adequate staffing; this need was engendered by the abrupt segregation of the staff of the former Division of Water Resources. This followed the legislation referred to in the beginning of this paper, whereby closely allied functions which had operated under a common head for over forty years were divided between two independent agencies. ${ }^{75}$ Formerly, there had been built up a highly-trained expert force, which was to a substantial extent individually interchangeable among closely-related functions. This practice was freely resorted to when required to balance variations in workload of such functions. The opportunity for interchange of personnel no longer exists with the formerly prevailing facility.

Further, the Board inherited a heavy "backlog" of pending applications which had accumulated over a long period of years. No substantial progress will be possible in reducing that burden until the Board's staffing problem is solved. This problem is intensified by the current well-known shortage of qualified engineers. The difficulties to be encountered in solving these

${ }^{75}$ See text at notes 1 and 2 supra. 
and other problems are fully appreciated by the Board, but it is attacking them energetically, with the firm conviction that in time they all can and will be overcome.

In conclusion, it is the objective of the Board to merit the confidence of the public which it serves, to acquire a reputation for probity, impartiality, and efficiency in performance of its duties, and, having acquired that reputation, to maintain it. 